\title{
Facile Synthesis of Sea Urchin-like Magnetic Copper Silicate Hollow Spheres for Efficient Removal of Hemoglobin in Human Blood
}

Yanwei Zhang, Min Zhang*, Jinbo Yang, Lei Ding, Jing Zheng, Jingli Xu*

College of Chemistry and Chemical Engineering, Shanghai University of Engineering

Science, Shanghai 201620, China.

Corresponding auther:E-mail address: congmingyang123@163.com, (M Zhang);

xujingli@sues.edu.cn, (JL Xu) 
Abstract: Well-defined superparamagnetic $\mathrm{Fe}_{3} \mathrm{O}_{4} /$ Metal-Silicate $\left(\mathrm{Cu}^{2+}, \mathrm{Ni}^{2+}, \mathrm{Mg}^{2+}\right)$ hollow spheres were fabricated using magnetite nanoparticles/silicon dioxide(denoted as $\left.\mathrm{SiO}_{2} @ \mathrm{Fe}_{3} \mathrm{O}_{4}\right)$ as templates. Firstly, monodisperse $\mathrm{SiO}_{2}$ spheres were obtained by classical stöber method, and $\mathrm{SiO}_{2} @ \mathrm{Fe}_{3} \mathrm{O}_{4}$ nanocomposites were fabricated in one-pot procedure through a solvothermal method, which were then converted into $\mathrm{Fe}_{3} \mathrm{O}_{4} /$ Metal-Silicate with hollow nanostructure by hydrothermal reaction between the silica core and metal ions in alkaline solution. The resultant $\mathrm{Fe}_{3} \mathrm{O}_{4} /$ Metal-Silicate composites exhibit both hollow structures and superparamagnetism. Furthermore, batch adsorption shows that the sea urchin-like $\mathrm{Fe}_{3} \mathrm{O}_{4} / \mathrm{CuSilicate}$ hollow spheres exhibited large specific surface area and an excellent adsorption capacity on bovine hemoglobin $(\mathrm{BHb})$. The resulting composites show not only a magnetic response to an externally applied magnetic field, but also can be a good adsorbent for removing the high abundant proteins(human hemoglobin $(\mathrm{HHb})$ ) in human blood.

Keywords: Sea Urchin, Copper silicate, Magnetite, Hemoglobin

\section{Introduction}

The development of efficient methods for the enrichment and purification of target proteins from complex samples is of vital importance in proteomics. [1-4] Currently, many target proteins are usually expressed with a tag for affinity separation, while His-tagged proteins are preferred in protein preparation. Among the existing protocols, immobilized metal affinity chromatography (IMAC) is the most widely used method. [5-7] However, it is unsuitable for complex biological samples containing suspended solids and fouling components. Therefore, 
establishment of novel methods for highly selective separation of His-rich proteins has been highly desired. Very recently, affinity particle-adsorbents have developed for the separation of His-rich or His-tagged proteins. [8-10] Generally, iminodiacetic acid (IDA), tris(carboxymethyl) ethylenediamine (TED) and nitrolotriacetic acid (NTA) can be used as chelating ligands. For example, nickel-nitrolotriacetic acid (Ni-NTA) complex-conjugated $\mathrm{Au} / \mathrm{Fe}_{3} \mathrm{O}_{4}, \mathrm{FePt}$ and silica were applied to separate His-tagged proteins. [11, 12] Chen etc have also reported a series of methods to synthesize IDA immobilized MNPs, and then charged with $\mathrm{Cu}^{2+}$ or $\mathrm{Ni}^{2+}$ for selective capture of His-rich bovine hemoglobin. [13-17] However, a major disadvantage of the above systems is a limited surface area as well as low surface metal ion density, which greatly hinder their practical application in protein separation. To overcome this problem, the well-designed hollow and mesoporous structured nanomaterials with higher metal density have emerged as powerful candidates for meeting the above mentioned requirements.

Recently, sacrificial-template synthesis utilizing the $\mathrm{SiO}_{2}$ as the template has been proposed as an efficient method to produce hollow metal silicate structures because it can avoid the template removal process and simultaneously produce a controllable mesoporous structures with higher metal density. Additionally, in comparison to the traditional silica and polymer porous hollow spheres, these metal silicate based hierarchical porous nanomaterials exhibited much higher stability in various chemical environments, high temperatures, and pressures. Due to their outstanding structural features, the hollow metal silicates have attracted great attention and have found wide application in fields such as drug delivery, catalyst support, adsorption and protein separation. [18-23] Wang etc have prepared $\mathrm{MgSiO}_{3}$ hollow spheres 
which exhibited a significantly high storage capacity of drug (2140 $\left.\mathrm{mg} \mathrm{DOX} \mathrm{g}^{-1}\right)$ and held a sustained release property, showing more potential for cancer therapy. [20] Wu etc have also synthesized the hollow nickel silicate spheres with hierarchical shells using similar strategy, which display a strong affinity on His-tagged proteins.[21] More recently, Jin etc al have developed a simple route to fabricate hollow rare earth silicates with mesoporous shells which was demonstrated to be good carriers for Au nanocatalysts. [22] These systems, however, still suffer from drawback such as not easy separation. Thus, combining such nanocarriers with superparamagnetic iron oxide nanoparticles (SPIONs) has been proposed. These magnetic hollow metal silicate materials realize their unique magnetic operability and zero remanence/coercivity, which greatly favor their recycling or enrichment abilities guided by external magnetic fields, when employed as heterogeneous catalysts, or protein adsorption.

In our previous report, it was proved that magnetic copper silicate hollow nanotubes exhibit the excellent performance on His-tagged proteins (BHb). [24] However, the expensive silver nanowires were used as the template to obtain the hollow structure, which restrict its application in protein adsorption. In view on these, we developed a simple, green and cheap process to obtain the uniform magnetic copper silicate hollow spheres as highly adsorbents for $\mathrm{BHb}$, and demonstrated their good adsorption ability and recyclability. The high temperature decompositions method combined with a facile hydrothermal approach is introduced to fabricate magnetic metal silicate hollow spheres $\left(\mathrm{Cu}^{2+} \mathrm{Ni}^{2+} \mathrm{Mg}^{2+}\right)$ with excellent monodispersity. It is worth noting that the hydrothermal treatment can not only etch the silica core to form the hollow structure, but also well disperse the magnetic nanoparticles into hollow structures, which endow the composites with the superparamganetic property. 
Remarkably, our magnetic copper silicate hollow spheres are shown to feature a much higher adsorption capacity of $\mathrm{BHb}\left(4416.8 \mathrm{mg} \mathrm{g}^{-1}\right)$ than previously reported silica-based nanoparticles.

\section{Experimental Section}

\subsection{Chemicals}

Tetraethoxysilane (TEOS, 95\%) was obtained from the Alfa Aesar Chemical Company, which was used directly without further purification. Triethylene glycol (TREG, 99\%) was from Aldrich. Copper chloride hydrate $\left(\mathrm{CuCl}_{2} \cdot 2 \mathrm{H}_{2} \mathrm{O}\right)$, ammonia solution (28-30\%), water and ethanol were used for all experiments. Other chemical reagent were purchased from shanghai chemical reagent company. Iron(III) acetylacetonate $\left(\mathrm{Fe}(\mathrm{acac})_{3}, 99 \%\right)$ was from energy chemical. Bovine hemoglobin(BHb) and Bovine serum albumin(BSA) were purchased from Shanghai Lanji Co. Ltd. (Shanghai, China).

\subsection{Preparation of $\mathrm{SiO}_{2}$ spheres}

$\mathrm{SiO}_{2}$ spheres were prepared via a modified stöber method.[25] In a typical reaction, $75 \mathrm{~mL}$ of ethanol, $10 \mathrm{~mL}$ of water, $3.2 \mathrm{~mL}$ of ammonia(27\%, aqueous solution) were mixed. Then $6 \mathrm{~mL}$ of TEOS was added the solution under vigorous stirring. After that, the reaction mixture was stirred for $12 \mathrm{~h}$ at room temperature. Then, the $\mathrm{SiO}_{2}$ spheres were collected by centrifugation and washed with water and ethanol several times, and then $\mathrm{SiO}_{2}$ spheres were collected and dispersed into an ethanol solution of $70 \mathrm{mg} / \mathrm{mL}$.

\subsection{Preparation of $\mathrm{Fe}_{3} \mathrm{O}_{4}$-coated $\mathrm{SiO}_{2}$ spheres}


$3 \mathrm{~mL} \mathrm{SiO}{ }_{2}$ spheres $(70 \mathrm{mg} / \mathrm{mL})$ ethanol solution and $40 \mathrm{~mL}$ triethylene glycol were added into the flask, and the mixture was then heated to $95{ }^{\circ} \mathrm{C}$ to remove ethanol. After the ethanol was removed completely, $320 \mathrm{mg}$ of the iron precursor $\mathrm{Fe}(\mathrm{acac})_{3}$ was added into the flask. The solution was sonicated for $5 \mathrm{~min}$. Finally, the mixture solution was then heated to $278{ }^{\circ} \mathrm{C}$ under vigorous stirring under the protection of nitrogen and kept at reflux for $30 \mathrm{~min}$. After cooling to room temperature, $40 \mathrm{~mL}$ ethanol was added to dilute the solution. Then the obtained composites were separated by an external magnet, which was washed with ethanol several times. The obtained composites were synthesized by the weight ratio of $\mathrm{SiO}_{2}: \mathrm{Fe}(\mathrm{acac})_{3}(1: 1.5)$, and the weight ratio of $\mathrm{SiO}_{2}$ and $\mathrm{Fe}(\mathrm{acac})_{3}$ to $1: 0.5,1: 6$, were also adjusted to synthesize $\mathrm{SiO}_{2} @ \mathrm{Fe}_{3} \mathrm{O}_{4}$ composites. For clarity, they were denoted as $\mathrm{SiO}_{2} @ \mathrm{Fe}_{3} \mathrm{O}_{4}(1: 0.5), \mathrm{SiO}_{2} @ \mathrm{Fe}_{3} \mathrm{O}_{4}(1: 1.5), \mathrm{SiO}_{2} @ \mathrm{Fe}_{3} \mathrm{O}_{4}(1: 6)$, respectively.

2.4 Preparation of sea urchin-like magnetic hollow copper silicate composites $\left(\mathrm{Fe}_{3} \mathrm{O}_{4} / \mathrm{CuSilicate}\right)$

In a typical procedure, $50 \mathrm{mg} \mathrm{SiO}_{2} @ \mathrm{Fe}_{3} \mathrm{O}_{4}$ spheres were dissolved in $20 \mathrm{~mL}$ deionized water. In addition, $1 \mathrm{mmol} \mathrm{CuCl} \cdot \mathrm{H}_{2} \mathrm{O}, 10 \mathrm{mmol} \mathrm{NH}_{4} \mathrm{Cl}$ and $1 \mathrm{~mL} \mathrm{NH}_{3} \cdot \mathrm{H}_{2} \mathrm{O}(28 \%)$ were dissolved in another $20 \mathrm{~mL}$ deionized water and ultrasonicated for $10 \mathrm{~min}$, and then the solutions were mixed well and poured into a Teflon-lined autoclave with volume of $50 \mathrm{~mL}$. The oven was heated to $140{ }^{\circ} \mathrm{C}$ and kept at that temperature for $12 \mathrm{~h}$. After cooling to room temperature, the precipitates were collected as magnetic copper silicate $\left(\mathrm{Fe}_{3} \mathrm{O}_{4} / \mathrm{CuSilicate}\right)$ by centrifugation and washed with ethanol for five times, and then dried at $60{ }^{\circ} \mathrm{C}$ for $3 \mathrm{~h}$. The $\mathrm{Fe}_{3} \mathrm{O}_{4} / \mathrm{NiSilicate}$ and $\mathrm{Fe}_{3} \mathrm{O}_{4} / \mathrm{MgSilicate}$ were obtained in a similar manner of preparation of $\mathrm{Fe}_{3} \mathrm{O}_{4} / \mathrm{CuSilicate}$. Notably, The $\mathrm{Fe}_{3} \mathrm{O}_{4} / \mathrm{CuSilicate}$ composites synthesized by $\mathrm{SiO}_{2} @ \mathrm{Fe}_{3} \mathrm{O}_{4}(1: 0.5)$, 
$\mathrm{SiO}_{2} @ \mathrm{Fe}_{3} \mathrm{O}_{4}(1: 1.5), \quad \mathrm{SiO}_{2} @ \mathrm{Fe}_{3} \mathrm{O}_{4}(1: 6)$ were denoted as $\mathrm{Fe}_{3} \mathrm{O}_{4} /$ CuSilicate(1:0.5), $\mathrm{Fe}_{3} \mathrm{O}_{4} /$ CuSilicate (1:1.5) and $\mathrm{Fe}_{3} \mathrm{O}_{4} /$ CuSilicate (1:6) respectively.

\subsection{In-vial adsorption and separation of proteins.}

All sample solutions were prepared in $20 \mathrm{mM}$ phosphate buffered solution (PBS) (pH 8.0). In the isothermal adsorption experiments, $0.25 \mathrm{mg}$ of $\mathrm{Fe}_{3} \mathrm{O}_{4} / \mathrm{CuSilicate}$ was vortex-mixed for 10 min with $5 \mathrm{~mL}$ of $\mathrm{BHb}$ solution at different concentrations ranging from 0.02 to $0.4 \mathrm{mg} \mathrm{mL}^{-1}$ in a centrifuge tube at room temperature and shaken for 3 hours. Then, the adsorbent-protein conjugates were isolated by external magnet. And the supernatants were collected and tested by UV-vis spectrometer respectively. In preferential adsorption, $0.25 \mathrm{mg}$ of $\mathrm{Fe}_{3} \mathrm{O}_{4} / \mathrm{CuSilicate}$ was vortex-mixed for $10 \mathrm{~min}$ with $5 \mathrm{~mL}$ of $\mathrm{BHb}$ solution, BSA solution, BHb/BSA binary solution, respectively and the concentration of all solutions is $0.2 \mathrm{mg} \mathrm{mL}^{-1}$. Then, the adsorbent-protein conjugates were isolated by magnetism and the supernatants were collected for UV-vis absorption testing.

\subsection{Instrumentation}

The data of UV-vis adsorption were obtained by using UV-2450 spectrophotometer (Shimadzu, Japan). The XRD pattern of each sample was recorded with a Shimadzu (Japan) D/Max-2500 diffractometer, using a monochromatized X-ray beam with nickel-filtered $\mathrm{Cu}=$ $\mathrm{K} \alpha$ radiation. The morphology and microstructures of the samples were characterized by scanning electron microscopy (SEM, JEOL-4800), transmission electron microscopy (TEM, JEOL-1011). The nitrogen adsorption-desorption isotherms were measured on a Quantachrome Autosorb AS-1 instrument. The magnetic properties were collected using vibrating sample magnetometry (VSM, MicroSense EV7) at room temperature. XPS of the 
$\mathrm{Fe}_{3} \mathrm{O}_{4} / \mathrm{CuSilicate}$ state was measured using Physical Electronics PHI 5600 XPS spectrophotometer with monochromatic $\mathrm{Al} \mathrm{K}_{-}(1486.6 \mathrm{eV})$ excitation source.

\section{Results and discussion}

\subsection{Synthesis and Characterization of Sea Urchin-like $\mathrm{Fe}_{3} \mathrm{O}_{4} / \mathrm{CuSilicate}$ Hollow Spheres}

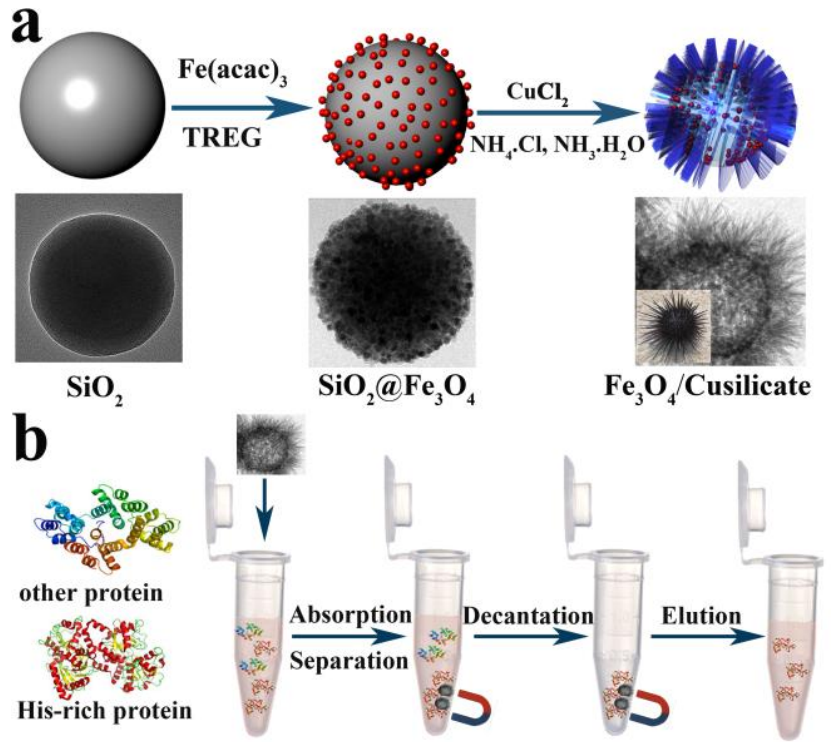

Scheme 1. (a) the synthetic procedure for the preparation of hollow $\mathrm{Fe}_{3} \mathrm{O}_{4} / \mathrm{CuSilicate}$ and (b) their application for removal of abundant protein in human blood with the help of an applied magnetic field by $\mathrm{Fe}_{3} \mathrm{O}_{4} / \mathrm{CuSilicate}$.

The fabrication process for hollow $\mathrm{Fe}_{3} \mathrm{O}_{4} /$ CuSilicate is depicted in scheme 1a. The synthetic process includes several steps: monodisperse $\mathrm{SiO}_{2}$ spheres were firstly obtained by classical stöber method, and magnetite nanoparticles/silicon dioxide (denoted as $\mathrm{SiO}_{2} @ \mathrm{Fe}_{3} \mathrm{O}_{4}$ ) nanocomposites were fabricated in one-pot procedure through a solvothermal method, which were then converted into $\mathrm{Fe}_{3} \mathrm{O}_{4} /$ CuSilicate with hollow nanostructure by hydrothermal reaction between the silica core and metal ions in alkaline solution. The $\mathrm{Fe}_{3} \mathrm{O}_{4}$ /NiSilicate and $\mathrm{Fe}_{3} \mathrm{O}_{4} / \mathrm{MgSilicate}$ were obtained in a similar manner of preparation of $\mathrm{Fe}_{3} \mathrm{O}_{4} / \mathrm{CuSilicate}$. The 
resultant $\mathrm{Fe}_{3} \mathrm{O}_{4} /$ Metal-Silicate composites exhibit both hollow structures and superparamagnetism. Furthermore, the sea urchin-like $\mathrm{Fe}_{3} \mathrm{O}_{4} / \mathrm{CuSilicate}$ composites can be a good adsorbent for removing the high abundant proteins in human blood (Scheme 1b).

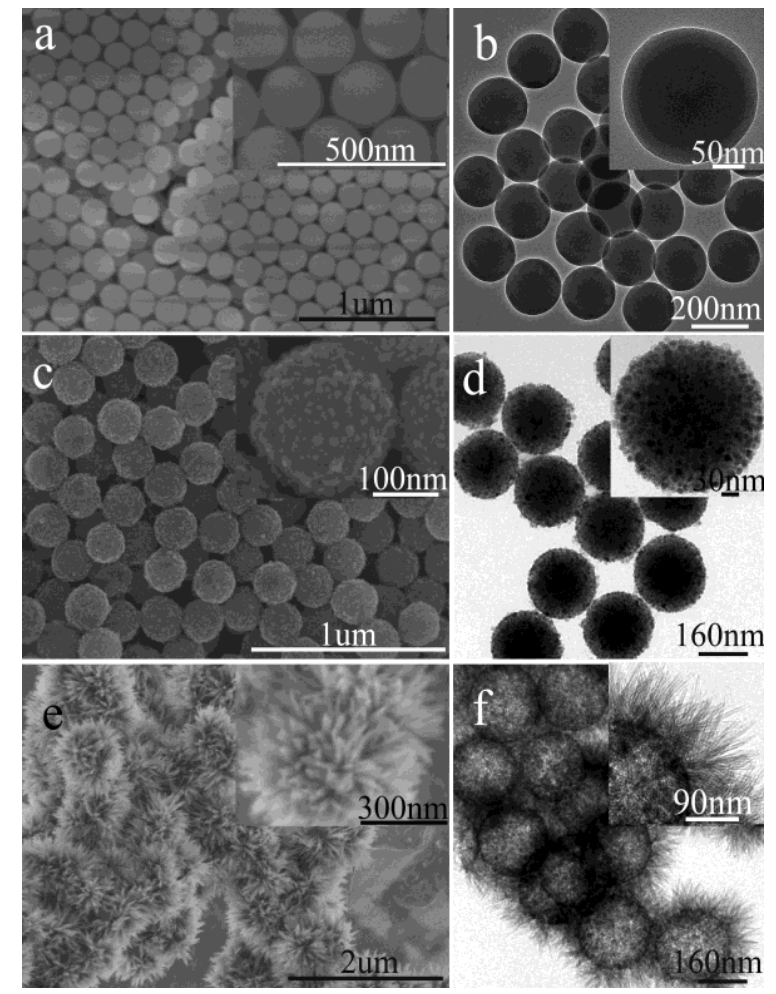

Figure 1. FSEM and TEM images of $\mathrm{SiO}_{2}(\mathrm{a}, \mathrm{b}), \mathrm{SiO}_{2} @ \mathrm{Fe}_{3} \mathrm{O}_{4} \operatorname{composites}(\mathrm{c}, \mathrm{d})$, and the as-prepared magnetic hierarchical copper silicate composites $\left(\mathrm{Fe}_{3} \mathrm{O}_{4} / \mathrm{CuSilicate}\right)(\mathrm{g}, \mathrm{h})$

The morphologies and structures of the products at different synthetic steps were observed by SEM and TEM. Firstly, silica spheres were prepared by the hydrolysis of TEOS in alcohol-ammonia mixture solution and the spheres had the diameter of $200 \mathrm{~nm}$ with very narrow size distribution (Figure 1a). Their diameters can be precisely controlled by tuning the TEOS concentrations and the ratio of the ethanol/water. Figure 1(a,b) show the FSEM and TEM images of $\mathrm{SiO}_{2}$ spheres, in which well dispersed particles with average diameter about $200 \mathrm{~nm}$ could be observed clearly, and the surface of the $\mathrm{SiO}_{2}$ was very smooth. After reacted with the $\mathrm{Fe}(\mathrm{acac})_{3}$ in TREG, the $\mathrm{SiO}_{2} @ \mathrm{Fe}_{3} \mathrm{O}_{4}$ composites could be easily obtained. 
Functionalizing the assembled nanostructures stabilizing with a layer of hydrophilic polyol molecules, these $\mathrm{SiO}_{2} @ \mathrm{Fe}_{3} \mathrm{O}_{4}$ composites are highly water-dispersed. Figure 1c and 1d show the FSEM and TEM images of the $\mathrm{SiO}_{2} @ \mathrm{Fe}_{3} \mathrm{O}_{4}$ composites, which can be clearly seen in the FESEM image that the $\mathrm{SiO}_{2} @ \mathrm{Fe}_{3} \mathrm{O}_{4}$ composites with very rough surface are actually composed of small primary nanocrystals. And the $\mathrm{Fe}_{3} \mathrm{O}_{4}$ particles with an average size of about $10 \mathrm{~nm}$ are uniformly distributed on the surface of the $\mathrm{SiO}_{2}$ spheres (Figure 1c-d). By adjusting the mass ratio of $\mathrm{Fe}(\mathrm{acac})_{3} / \mathrm{SiO}_{2}$, the size and density of the $\mathrm{Fe}_{3} \mathrm{O}_{4}$ particles on the $\mathrm{SiO}_{2}$ can be exactly controlled. For example, the mass ratios of $\mathrm{SiO}_{2} / \mathrm{Fe}(\mathrm{acac})_{3}(1 / 0.5)$ can lead to the synthesis of $\mathrm{SiO}_{2} @ \mathrm{Fe}_{3} \mathrm{O}_{4}$ composites with lower magnetic response while $\mathrm{SiO}_{2} @ \mathrm{Fe}_{3} \mathrm{O}_{4}$ composites with higher magnetic response can also be obtained by increasing the mass ratio of $\mathrm{SiO}_{2} / \mathrm{Fe}(\mathrm{acac})_{3}(1 / 6)$ (Figure $\left.\mathrm{S} 1\right)$. These fully indicate that the concentration of iron precursor had an effect on both the attachment and the magnetite nanocrystal itself. When the concentration of iron precursor was doubled, the average size of magnetite nanoparticles was increased from 8 to $10 \mathrm{~nm}$ (Figure S1a, c), which can be attributed to the increased amount of available iron source for particle growth, whereas diluted iron source concentration yielded silica nanospheres with less and smaller magnetite nanoparticles (Figure S1), and the test results are also in accordance with Qu etc's work. [26] Subsequently, when hydrothermally treated in $\mathrm{CuCl}_{2}$ and ammonia solution, the $\mathrm{SiO}_{2}$ core of the $\mathrm{SiO}_{2} @ \mathrm{Fe}_{3} \mathrm{O}_{4}$ spheres is gradually dissolved in the form of silicate anions. Driven by the interfacial reaction between $\mathrm{Cu}^{2+}$ cations and the silicate anions, copper silicate nanotubes are grown readily around the surface of the $\mathrm{SiO}_{2} @ \mathrm{Fe}_{3} \mathrm{O}_{4}$ core to form the CuSilicate shell. Meanwhile, the decorated $\mathrm{Fe}_{3} \mathrm{O}_{4}$ on the surface of $\mathrm{SiO}_{2}$ were entrapped by growing CuSilicate 
shell. Herein, the $\mathrm{SiO}_{2}$ core serves not only as the precursor for the CuSilicate shell but also as a sacrificial template for the hollow structure. The morphology of the $\mathrm{Fe}_{3} \mathrm{O}_{4} /$ CuSilicate is examined by the FESEM. As shown in Figure 1e-f, the products exhibit an urchin-like shape with an average diameter of about $380 \mathrm{~nm}$ and consist of aligned needle-like nanosize primary particles. TEM further confirms that the synthesized microspheres possess a typical hollow structure. It can be clearly seen in Figure 1f that the microspheres are composed of many dark $\mathrm{Fe}_{3} \mathrm{O}_{4}$ particles individually encapsulated in ultrafine nanoneedle-assembled shells. The average size of the microspheres is approximately $380 \mathrm{~nm}$, and the shell thickness is about $90 \mathrm{~nm}$. In addition, the $\mathrm{SiO}_{2} @ \mathrm{Fe}_{3} \mathrm{O}_{4}$ composites with different magnetic nanoparticles loading were also testified for the method's versatility. From the Figure 2, the similar results were also achieved by the hydrothermal methods. Remarkably, when the $\mathrm{SiO}_{2} @ \mathrm{Fe}_{3} \mathrm{O}_{4}$ composites(1:0.5) was used to be the template, an interesting phenomena was observed. Compared to the as-prepared products from the $\mathrm{SiO}_{2} @ \mathrm{Fe}_{3} \mathrm{O}_{4} \operatorname{composites}(1: 1.5,1: 6)$, the magnetic nanoparticles were scattered onto the new-generated copper silicate(Figure 2b), while as for the products from the $\mathrm{SiO}_{2} @ \mathrm{Fe}_{3} \mathrm{O}_{4}$ composites $(1: 1.5,1: 6)$, the magnetic nanoparticles were still be confined into the hollow structures encircled by CuSilicate nanotubes(Figure 1f, Figure 2d). These will be attributed to the dense $\mathrm{Fe}_{3} \mathrm{O}_{4}$ and stable layer from the high magnetic loading magnetic $\mathrm{SiO}_{2} @ \mathrm{Fe}_{3} \mathrm{O}_{4} \operatorname{composites}(1: 1.5,1: 6)$, while the loose $\mathrm{Fe}_{3} \mathrm{O}_{4}$ layer for the $\mathrm{SiO}_{2} @ \mathrm{Fe}_{3} \mathrm{O}_{4}$ composites (1:0.5) was easy to collapse after hydrothermal treatment under this condition. 


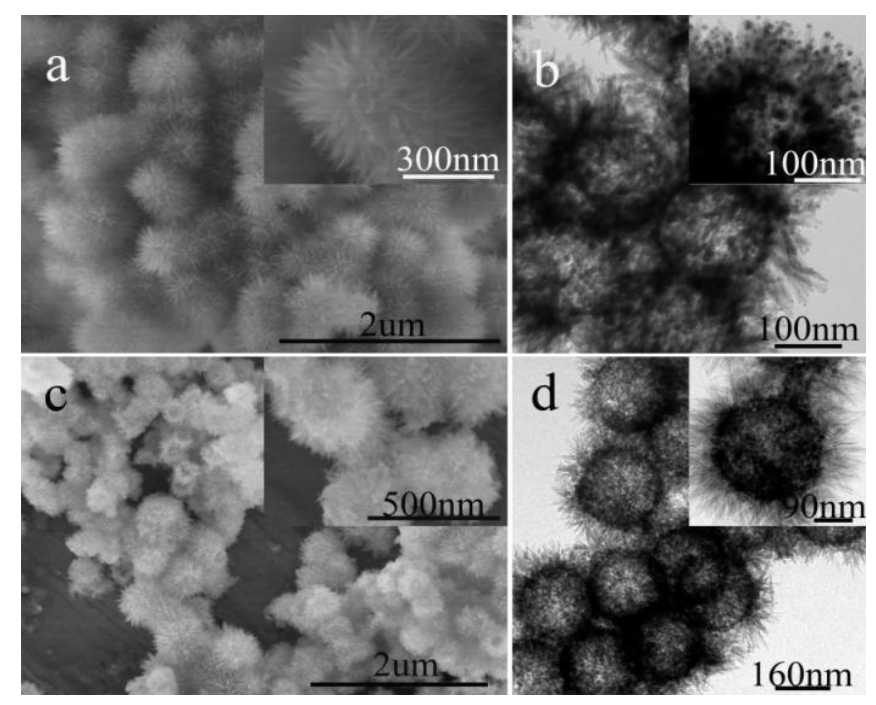

Figure 2. FSEM and TEM images of $\mathrm{Fe}_{3} \mathrm{O}_{4} / \mathrm{CuSilicate}$ composites $(1: 0.5)(\mathrm{a}, \mathrm{b})$ and $(1: 6)(\mathrm{c}, \mathrm{d})$

Moreover, variable sized $\mathrm{SiO}_{2} @ \mathrm{Fe}_{3} \mathrm{O}_{4}$ can be easily obtained by simply using silica spheres of different diameters as template. The silica spheres with larger diameter were also used as the template to synthesize the $\mathrm{SiO}_{2} @ \mathrm{Fe}_{3} \mathrm{O}_{4}$, which will lead to $\mathrm{Fe}_{3} \mathrm{O}_{4} / \mathrm{CuSilicate}$ with larger diameter. As shown in Figure S2, silica nanoparticles with sizes of $\sim 300 \mathrm{~nm}$ are all covered with a layer of magnetite nanoparticles, and no detachment of $\mathrm{Fe}_{3} \mathrm{O}_{4}$ was observed in any of the product. After hydrothermally treated in $\mathrm{CuCl}_{2}$ and ammonia solution, the $\mathrm{Fe}_{3} \mathrm{O}_{4} / \mathrm{CuSilicate}$ with larger diameter can be obtained by this method. Meanwhile, the $\mathrm{CuCl}_{2}$ was replaced by $\mathrm{NiCl}_{2}, \mathrm{MgCl}_{2}$, respectively, to further verify the versatility of this method. The magnetic hierarchical structure of magnesium, nickel silicate hollow spheres were obtained, which is well matched our assumption. From the FSEM and TEM images of the products (Figure $\mathrm{S} 3\left(\mathrm{a}, \mathrm{b}, \mathrm{d}, \mathrm{e}\right.$ ), it is observed that the $\mathrm{SiO}_{2}$ cores was totally consumed and formed a magnetic magnesium, nickel silicate hollow spheres. Similar to that of the $\mathrm{Fe}_{3} \mathrm{O}_{4} / \mathrm{CuSilicate}$, and the magnetic nanoparticles were all entrapped by the growing the magnesium, nickel silicate layer, which were proved by the XRD pattern of the as-prepared products between the $\mathrm{SiO}_{2} @ \mathrm{Fe}_{3} \mathrm{O}_{4}$ with $\mathrm{MgCl}_{2}, \mathrm{NiCl}_{2}$ in alkaline solution (Figure S4). [21, 
27-30] In addition, the BET of the as-prepared magnetic hierarchical magnesium/nickel silicate hollow nanospheres are $443 \mathrm{~m}^{2} \mathrm{~g}^{-1}, \quad 172 \mathrm{~m}^{2} \mathrm{~g}^{-1}$ respectively. Nitrogen adsorption-desorption isotherm of the magnetic magnesium/ nickel silicate hollow spheres are shown in Figure S4(c, f). Together with the above data, these fully indicate that the magnetic metal silicate composites with hollow structures can be successfully synthesized by this method.

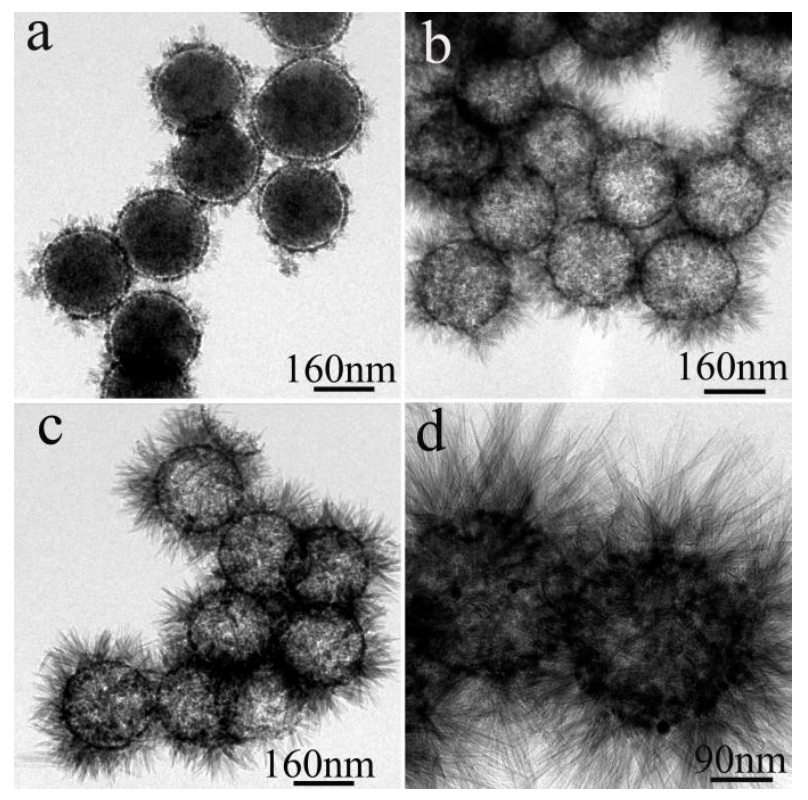

Figure 3. TEM images of products synthesized under different hydrothermal time: $3 \mathrm{~h}(\mathrm{a}, \mathrm{b})$, $12 \mathrm{~h}(\mathrm{c}), 24 \mathrm{~h}(\mathrm{~d})$.

To investigate the formation of the $\mathrm{Fe}_{3} \mathrm{O}_{4} / \mathrm{CuSilicate}$ composites with hollow structures, time-dependent TEM observation of the hydrothermal process is also conducted to understand how the hollow $\mathrm{Fe}_{3} \mathrm{O}_{4} /$ CuSilicate nanostructures are generated. And the TEM images of the corresponding magnetic copper silicate products with different reaction time from 0 to 24 hours are shown in Figure 3. It can be clearly seen that $\mathrm{SiO}_{2} @ \mathrm{Fe}_{3} \mathrm{O}_{4}$, the chemical template, has a rough surface and diameters of $260 \mathrm{~nm}$ from Figure 3a. Along with the hydrothermal reaction was conducted up to 3 hours, the surface of $\mathrm{SiO}_{2} @ \mathrm{Fe}_{3} \mathrm{O}_{4}$ spheres become rougher 
and surrounded by a lot of short copper silicate nanotubes, and the obvious magnetic hollow copper silicate sphere have also been observed (Figure 3b), which clearly indicates the in situ dissolution of the $\mathrm{SiO}_{2}$ and formation of the copper silicate nanotube. When the reaction was prolonged to 12 hours, the core of silica spheres was totally consumed and the length of copper silicate nanotubes is become longer. Moreover, the magnetic nanoparticles were embedded into the hollow structures encircled by the copper silicate nanotubes, indicating the formation of a typical magnetic hollow structure (Figure 3c). This fully indicates that the small size of $\mathrm{Fe}_{3} \mathrm{O}_{4}$ layer was stable in the hydrothermal reaction for 12 hours. If the reaction time was further prolonged to 24 hours, the growth of the copper silicate nanotubes would be processed continuously, and then a longer and denser copper silicate shell with hierarchical nanostructure was achieved. Figure $3 \mathrm{~d}$ shows the TEM image of the hollow magnetic copper silicate spheres synthesized after $24 \mathrm{~h}$. Compared with Figure 3c, the copper silicate nanotubes is much longer and thicker, which indicates that the longer reaction time can produce more copper silicate materials in the product. However, in the as-prepared products, the black nanoparticles were found in the as-prepared product (data not shown), which were proved to $\mathrm{Fe}_{3} \mathrm{O}_{4}$ by using the magnet. This means that the $\mathrm{Fe}_{3} \mathrm{O}_{4}$ layer on $\mathrm{SiO}_{2}$ spheres became not stable under hydrothermal reaction for 24 hours. Based on the above mentioned, the 12 hours was selected to produce the magnetic hollow copper silicate composites. Along with the current shape transformation process, since the crystallites located in the inner cores have higher surface energies, the conventional Ostwald ripening (outward ripening) will occur in the centre of these $\mathrm{SiO}_{2}$ particles, which result in hollow sphere structures. The growth mechanism of hierarchical hollow sphere and results of the research are of significance in 
synthesis of rationally designed nanostructures.

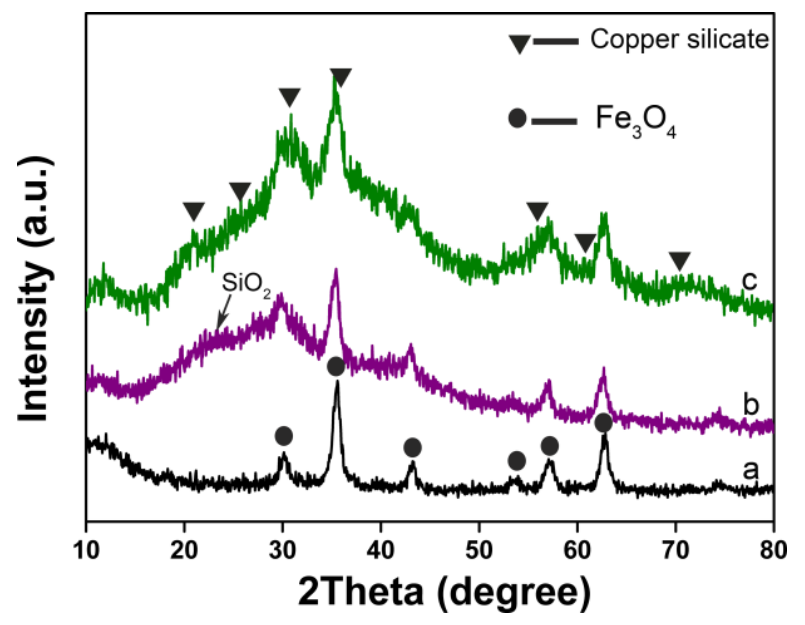

Figure 4. X-Ray diffraction patterns of $\mathrm{Fe}_{3} \mathrm{O}_{4}(\mathrm{a})$, the $\mathrm{SiO}_{2} @ \mathrm{Fe}_{3} \mathrm{O}_{4}$ composites(b) and magnetic hollow copper silicate spheres (c)

The XRD pattern (Figure 4a) of the $\mathrm{Fe}_{3} \mathrm{O}_{4}$ shows broad diffraction peaks at $2 \theta=30.2^{\circ}, 35.6^{\circ}$, $43.3^{\circ}, 57.3^{\circ}$ and $62.6^{\circ}$ could be attributed to the structure (220), (311), (400), (511) and (440) planes of the $\mathrm{Fe}_{3} \mathrm{O}_{4}$, which match well with the black line for the magnetite(JCPDS file No. 19-0629).[31, 32] As for $\mathrm{SiO}_{2} @ \mathrm{Fe}_{3} \mathrm{O}_{4}\left(\right.$ Figure 4b), the obvious broad peak at $23^{\circ}$ for the $\mathrm{SiO}_{2}$ cores is clearly observed, indicating the existence of the $\mathrm{SiO}_{2}$ in the $\mathrm{SiO}_{2} @ \mathrm{Fe}_{3} \mathrm{O}_{4}$ composites. According to the Scherer equation, the average crystallite size of $\mathrm{Fe}_{3} \mathrm{O}_{4}$ in the $\mathrm{SiO}_{2} @ \mathrm{Fe}_{3} \mathrm{O}_{4}$ composites which is calculated based on the XRD pattern (311) is approximately $21.35 \mathrm{~nm}$. This is due to that the silica can not provide enough space to load more magnetic nanoparticles, leading to the aggregation of the $\mathrm{Fe}_{3} \mathrm{O}_{4}$. Moreover, the hydrogen bonding interaction with the adjacent magnetic nanoparticles are not beneficial for the dispersion of the $\mathrm{Fe}_{3} \mathrm{O}_{4}$. Figure 4c shows the XRD pattern of the hollow $\mathrm{Fe}_{3} \mathrm{O}_{4} / \mathrm{CuSilicate}$ composites in which the diffraction peaks assigned to the magnetite can be clearly visible, this fully indicates that the decorated $\mathrm{Fe}_{3} \mathrm{O}_{4}$ was not stripped from the surface of the $\mathrm{SiO}_{2}$ in the 
hydrothermal reaction. More importantly, after hydrothermal treatment in $\mathrm{NH}_{3}-\mathrm{NH}_{4} \mathrm{Cl}$ buffer, the XRD peaks broadening of the $\mathrm{Fe}_{3} \mathrm{O}_{4}$ was observed. The average crystallite $\mathrm{Fe}_{3} \mathrm{O}_{4}$ size of the hollow $\mathrm{Fe}_{3} \mathrm{O}_{4} / \mathrm{CuSilicate}$ composite was decreased to $13.94 \mathrm{~nm}$, which is also calculated based on the XRD pattern (311) of the hollow $\mathrm{Fe}_{3} \mathrm{O}_{4} / \mathrm{CuSilicate}$ composite. Thanks to the hollow structures of $\mathrm{Fe}_{3} \mathrm{O}_{4} / \mathrm{CuSilicate}$ composite, the $\mathrm{Fe}_{3} \mathrm{O}_{4}$ nanoparticles were well dispersed into the hollow structures, which greatly decrease the aggragation of the $\mathrm{Fe}_{3} \mathrm{O}_{4}$. All weak diffraction peaks of XRD pattern can be clearly indexed to copper silicate (JCPDS card no. 32-0346).[33] It confirms the formation of magnetite-copper silicate composites. Due to the nanocrystalline nature of the magnetic copper silicate hollow spheres, the peaks show some broadening.
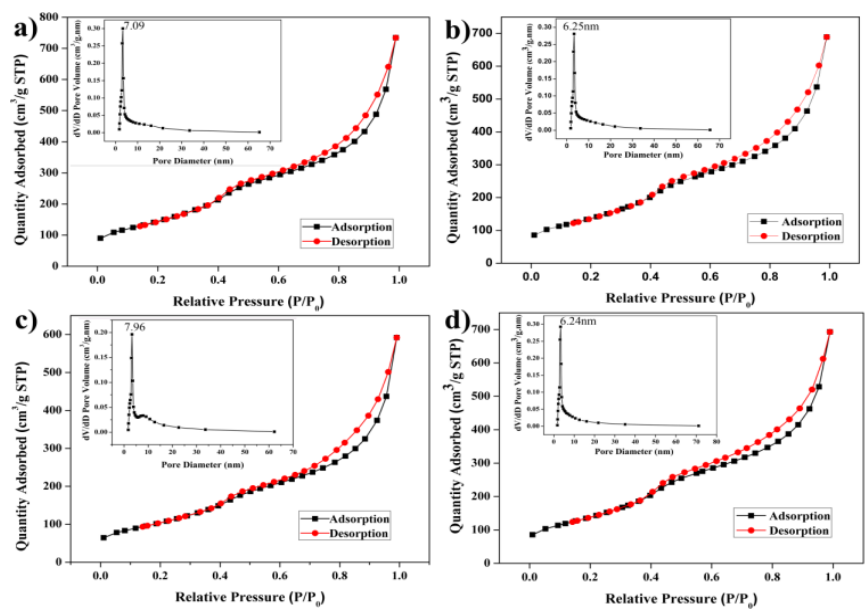

Figure 5. Nitrogen adsorption-desorption isotherm of the as-prepared magnetic hierarchical copper silicate hollow nanosphere(a, 1:0.5, b 1:1.5, c, 1:6, d(1:1.5) with the larger diameter of $\mathrm{SiO}_{2}$.

The Nitrogen adsorption-desorption isotherms and pore size distribution curves of $\mathrm{Fe}_{3} \mathrm{O}_{4} / \mathrm{CuSilicate}$ were analyzed (Figure 5). The $\mathrm{Fe}_{3} \mathrm{O}_{4} / \mathrm{CuSilicate}(1: 1.5)$ samples show a BET surface area of $503 \mathrm{~m}^{2} \mathrm{~g}^{-1}$ and a total pore volume of $0.78 \mathrm{~cm}^{3} \cdot \mathrm{g}^{-1}$. Such a high surface area 
was attributed to the hollow structures and meosporous shell. The isotherm exhibits a type-IV profile, which have typical hysteresis loops of mesoporous materials. The pore size distribution of $\mathrm{Fe}_{3} \mathrm{O}_{4} / \mathrm{CuSilicate}$ exhibited a sharp distribution (Figure 5b inset), with a peak centered at $\sim 6.25 \mathrm{~nm}$. Moreover, the BET surface area of the $\mathrm{Fe}_{3} \mathrm{O}_{4} / \mathrm{CuSilicate}$ can be easily adjusted by using different $\mathrm{SiO}_{2} @ \mathrm{Fe}_{3} \mathrm{O}_{4}$ composites as template. The $\mathrm{Fe}_{3} \mathrm{O}_{4} / \mathrm{CuSilicate}(1: 0.5)$ generated from $\mathrm{SiO}_{2} @ \mathrm{Fe}_{3} \mathrm{O}_{4}(1: 0.5)$ composites samples show a BET surface area of 538.91 $\mathrm{m}^{2} \mathrm{~g}^{-1}$ (Figure 5b), while with $\mathrm{SiO}_{2} @ \mathrm{Fe}_{3} \mathrm{O}_{4}(1: 6)$ composites as the templates, the BET surface area of $\mathrm{Fe}_{3} \mathrm{O}_{4} / \mathrm{CuSilicate}(1: 6)$ was decreased to $387.36 \mathrm{~cm}^{3} \cdot \mathrm{g}^{-1}$ (Figure 5c). As for the $\mathrm{Fe}_{3} \mathrm{O}_{4} / \mathrm{CuSilicate}$ synthesized by the larger diameter of $\mathrm{SiO}_{2} @ \mathrm{Fe}_{3} \mathrm{O}_{4}(350 \mathrm{~nm})$ as template, the BET surface area was $509.14 \mathrm{~m}^{2} \mathrm{~g}^{-1}$,(Figure 5d). The detailed BET specific surface area for the $\mathrm{Fe}_{3} \mathrm{O}_{4} / \mathrm{CuSilicate}$ synthesized by different mass ratios of $\mathrm{SiO}_{2} @ \mathrm{Fe}_{3} \mathrm{O}_{4}$ and larger diameter of $\mathrm{SiO}_{2} @ \mathrm{Fe}_{3} \mathrm{O}_{4}$ were listed in Table 1, thus, the BET surface area of the $\mathrm{Fe}_{3} \mathrm{O}_{4} /$ CuSilicate can be easily adjusted by using different amount of magnetic nanoparticles decorated silica spheres or larger diameter of $\mathrm{SiO}_{2} @ \mathrm{Fe}_{3} \mathrm{O}_{4}$ composites.

Table 1. Structure parameters of various of $\mathrm{Fe}_{3} \mathrm{O}_{4} / \mathrm{CuSilicate}$ synthesized by different mass ratios of $\mathrm{SiO}_{2} @ \mathrm{Fe}_{3} \mathrm{O}_{4}$ and larger diameter of $\mathrm{SiO}_{2} @ \mathrm{Fe}_{3} \mathrm{O}_{4}$

\begin{tabular}{ccc}
\hline Sample & BET surfae area $\left(\mathrm{m}^{2} \mathrm{~g}^{-1}\right)$ & BJH pore volume $\left(\mathrm{cm}^{3} \mathrm{~g}^{-1}\right)$ \\
\hline $\mathrm{Fe}_{3} \mathrm{O}_{4} /$ CuSilicate $(1: 0.5)$ & 538.91 & 0.83 \\
$\mathrm{Fe}_{3} \mathrm{O}_{4} /$ CuSilicate $(1: 1.5)$ & 503.71 & 0.78 \\
$\mathrm{Fe}_{3} \mathrm{O}_{4} / \mathrm{CuSilicate}(1: 6)$ & 387.36 & 0.63 \\
$\mathrm{Fe}_{3} \mathrm{O}_{4} /$ CuSilicate (1:1.5) & & 0.79 \\
$($ larger diameter $)$ & 509.14 & \\
\hline
\end{tabular}



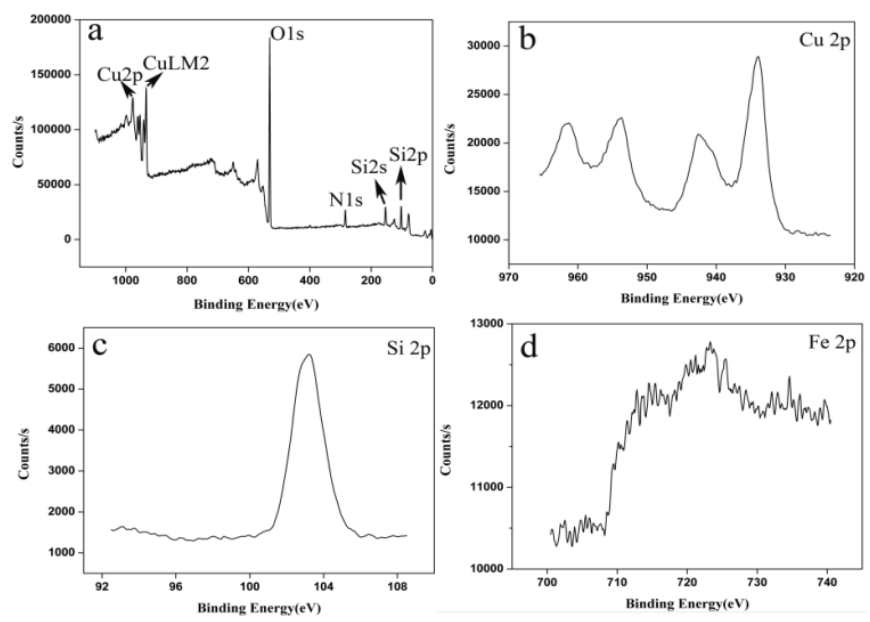

Figure 6. XPS spectra wide scan of the $\mathrm{Fe}_{3} \mathrm{O}_{4} / \mathrm{CuSilicate}(\mathrm{a}), \mathrm{Cu} 2 \mathrm{p}$ spectra of the $\mathrm{Fe}_{3} \mathrm{O}_{4} / \mathrm{CuSilicate}$ (b), Si2p of the $\mathrm{Fe}_{3} \mathrm{O}_{4} / \mathrm{CuSilicate}$ (c), and $\mathrm{Fe} 2 \mathrm{p}$ spectra of the $\mathrm{Fe}_{3} \mathrm{O}_{4} / \mathrm{CuSilicate}(\mathrm{d})$.

X-ray photoelectron spectroscopy (XPS) (Figure 6) was employed to analyze the chemical and oxidation states of the $\mathrm{Fe}_{3} \mathrm{O}_{4} / \mathrm{CuSilicate}$ composites. All peaks on XPS curve for the composites are ascribed to $\mathrm{Cu}, \mathrm{Si}, \mathrm{O}, \mathrm{N}$ and $\mathrm{C}$. No other peaks can be observed. The peaks at 933.92 and $953.91 \mathrm{eV}$ can be addressed to the binding energy of $\mathrm{Cu} 2 \mathrm{p} 3 / 2$ and $\mathrm{Cu} 2 \mathrm{p} 1 / 2$, respectively, which fully indicates that copper ion was existed in the final product. [34] As shown in Figure 6a, the peaks of Si 2s and Si 2p could be observed, and the binding energy of Si $2 p$ was $103.0 \mathrm{eV}$ (Figure 6c), which suggested that all samples were silicates. [35] Notably, the peaks corresponded to the binding energies of Fe2p1/2 and Fe2p3/2 at 710.4 and $723.9 \mathrm{eV}$ were not found (Figure 6d), which is due to that the $\mathrm{Fe}_{3} \mathrm{O}_{4}$ cores are entrapped with a shell thickness of CuSilicate layer above $10 \mathrm{~nm}$. [36, 37] 


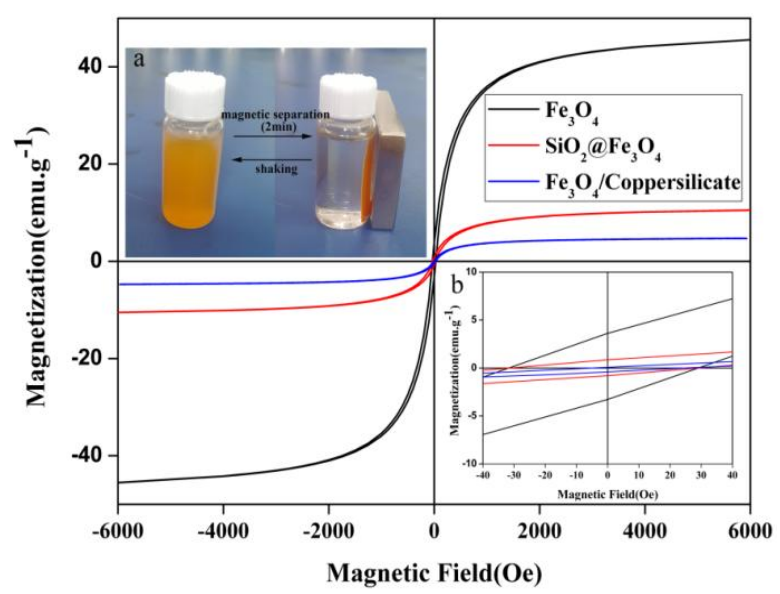

Figure 7. Hysteresis loops of $\mathrm{Fe}_{3} \mathrm{O}_{4}, \mathrm{SiO}_{2} @ \mathrm{Fe}_{3} \mathrm{O}_{4}, \mathrm{Fe}_{3} \mathrm{O}_{4} / \mathrm{CuSilicate}$ composites. The inset is a photograph for the magnetic separation (a) and magnified hysteresis loops at low applied magnetic fields (b)

The magnetic hysteresis loops were measured by a vibrating sample magnetometer (VSM) at room temperature (Figure 7). As described in Figure 7, the saturation magnetizations of $\mathrm{Fe}_{3} \mathrm{O}_{4}$, $\mathrm{SiO}_{2} @ \mathrm{Fe}_{3} \mathrm{O}_{4}, \quad \mathrm{Fe}_{3} \mathrm{O}_{4} / \mathrm{CuSilicate}$ composites are approximately 45.4, 10.3, $4.7 \mathrm{emu} / \mathrm{g}$, respectively(listed in Table 2). To calculate the amount of $\mathrm{Fe}_{3} \mathrm{O}_{4}$ in the magnetic composites, the pure $\mathrm{Fe}_{3} \mathrm{O}_{4}$ NPs were also prepared, which is copied the experimental procedure of $\mathrm{SiO}_{2} @ \mathrm{Fe}_{3} \mathrm{O}_{4}$ composites. The only difference of both is that no $\mathrm{SiO}_{2}$ templates were added. Based on magnetic hysteresis data, the mass amount of $\mathrm{Fe}_{3} \mathrm{O}_{4}$ of composites is about $22.75 \%$ for $\mathrm{SiO}_{2} @ \mathrm{Fe}_{3} \mathrm{O}_{4}$ and $10.41 \%$ for $\mathrm{Fe}_{3} \mathrm{O}_{4} /$ CuSilicate. On the other hand, as shown in the corresponding magnified hysteresis loops at low applied magnetic fields (see inset of Figure 7b), the coercivity (HC) values of the samples vary differently: $3.58 \mathrm{emu} / \mathrm{g}\left(\mathrm{Fe}_{3} \mathrm{O}_{4}\right), 0.87$ emu/g $\left(\mathrm{SiO}_{2} @ \mathrm{Fe}_{3} \mathrm{O}_{4}\right)$, and $0.11 \mathrm{emu} / \mathrm{g}\left(\mathrm{Fe}_{3} \mathrm{O}_{4} / \mathrm{CuSilicate}\right)$ (listed in Table 2). The difference among the coercivity (HC) values for the above samples can be explained as follows: As known, the increase of $\mathrm{HC}$ is attributed to the aggregation of nanometer size of $\mathrm{Fe}_{3} \mathrm{O}_{4}$ particles. Due to large area-to-volume ratio of smaller magnetic nanoparticles, they tend to be 
easily aggregated. Decoration the $\mathrm{Fe}_{3} \mathrm{O}_{4}$ particles onto the silica spheres can effectively decrease the aggregation of the $\mathrm{Fe}_{3} \mathrm{O}_{4}$ nanoparticles. After hydrothermal treatment in alkaline solution, the new-generated hollow structures can hold more $\mathrm{Fe}_{3} \mathrm{O}_{4}$ nanoparticles, which further improve the dispersion of the $\mathrm{Fe}_{3} \mathrm{O}_{4}$ nanoparticles. These fully illustrate that the $\mathrm{HC}$ values of the as-prepared $\mathrm{Fe}_{3} \mathrm{O}_{4}$ samples are all greater than that of the other samples, while the $\mathrm{HC}$ values of $\mathrm{Fe}_{3} \mathrm{O}_{4} / \mathrm{CuSilicate}$ is lower than that of $\mathrm{SiO}_{2} @ \mathrm{Fe}_{3} \mathrm{O}_{4}$. Moreover, the obtained $\mathrm{Fe}_{3} \mathrm{O}_{4} / \mathrm{CuSilicate}$ can be easily separated from the reaction solution by applying a relatively low magnetic field(Figure 7a).

Table 2. The saturation magnetizations and Coercivity of $\mathrm{Fe}_{3} \mathrm{O}_{4}, \mathrm{SiO}_{2} @ \mathrm{Fe}_{3} \mathrm{O}_{4}$ and $\mathrm{Fe}_{3} \mathrm{O}_{4} / \mathrm{CuSilicate}$

Saturation magnetization

Sample

Coercivity $(\mathrm{emu} / \mathrm{g})$

$(\mathrm{emu} / \mathrm{g})$

\begin{tabular}{ccc}
\hline $\mathrm{Fe}_{3} \mathrm{O}_{4}$ & 45.4 & 3.58 \\
$\mathrm{SiO}_{2} @ \mathrm{Fe}_{3} \mathrm{O}_{4}$ & 10.3 & 0.87 \\
$\mathrm{Fe}_{3} \mathrm{O}_{4} / \mathrm{CuSilicate}$ & 4.7 & 0.11 \\
\hline
\end{tabular}

\subsection{Adsorption and Removal of Hemoglobin of $\mathrm{Fe}_{3} \mathrm{O}_{4} / \mathrm{CuSilicate}$}

The $\mathrm{Fe}_{3} \mathrm{O}_{4} / \mathrm{CuSilicate}(1: 1.5)$ composites was tested for the adsorption of $\mathrm{BHb}$ in $20 \mathrm{~mm}$ phosphate buffer ( $\mathrm{pH}$ 8.0) by the batch experiment. Firstly, $0.5 \mathrm{mg}$ of $\mathrm{Fe}_{3} \mathrm{O}_{4} / \mathrm{CuSilicate}$ was mixed with $5 \mathrm{~mL}$ of various concentrations of $\mathrm{BHb}$ solution $\left(0.02-0.4 \mathrm{mg} \mathrm{mL}^{-1}\right)$. Then, the mixture was shaken at $25{ }^{\circ} \mathrm{C}$ for $12 \mathrm{~h}$ to reach adsorption equilibrium. Analysis of Figure 8 
reveals that the $\mathrm{BHb}$ was effectively adsorbed. The $\mathrm{BHb}$ adsorption isotherm could be described by the Langmuir equation, Equation :

$$
q=\frac{q_{m} c}{K_{d}+c}
$$

where $c\left(\mathrm{mg} \mathrm{mL}^{-1}\right)$ and $q\left(\mathrm{mg} \mathrm{g}^{-1}\right)$ are the aqueous protein concentration and the amount of adsorbed protein at equilibrium, respectively. $q_{\mathrm{m}}\left(\mathrm{mg} \mathrm{g}^{-1}\right)$ is the maximum adsorption capacity and $K_{\mathrm{d}}\left(\mathrm{mg} \mathrm{mL} \mathrm{m}^{-1}\right)$ is the dissociation constant. By fitting the experimental data to the Langmuir equation(Figure 8b), and Freundlich equation(Figure S5), The $\mathrm{R}^{2}$ value of the Langmuir model (0.9997) is very close to 1 and it is much larger than that of the Freundlich isotherm (0.8872). Hence, the Langmuir model is more appropriate than the Freundlich model for describing the adsorption behavior of $\mathrm{BHb}$ onto $\mathrm{Fe}_{3} \mathrm{O}_{4} / \mathrm{CuSilicate}$. The $Q_{\mathrm{m}}$ and $K_{\mathrm{d}}$ of Langmuir model are estimated to be $4416.8 \mathrm{mg} \mathrm{g}^{-1}$ and $0.085 \mathrm{mg} \mathrm{mL}^{-1}$ respectively and $\mathrm{K}_{\mathrm{F}}$ and $\mathrm{n}$ of Freundlich isotherm are estimated to 491.13 and 2.01 respectively(Table. S1). We compared the $Q_{\mathrm{m}}$ of $\mathrm{Fe}_{3} \mathrm{O}_{4}$ with those reported previously using different absorbents (Table 3). It can be seen that the adsorbent had the best maximum adsorption capacity of all the absorbents. The sea urchin-like structure and high density of $\mathrm{Cu}^{2+}$ of $\mathrm{Fe}_{3} \mathrm{O}_{4} / \mathrm{CuSilicate}$ may be responsible for the ultra high adsorption capacity.
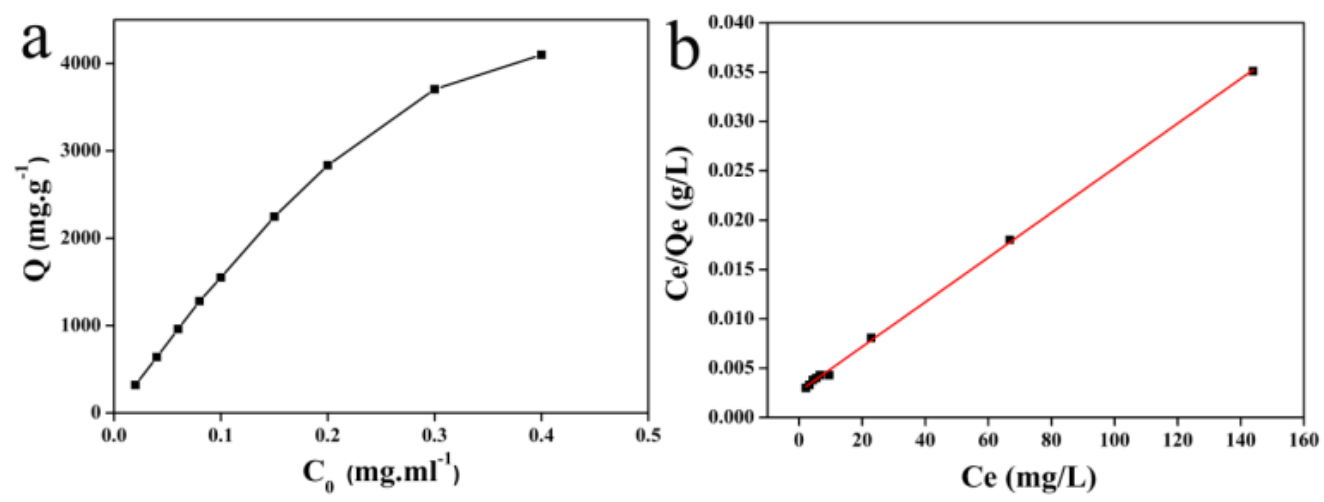
Figure 8. Adsorption isotherm of $\mathrm{BHb}$ on $\mathrm{Fe}_{3} \mathrm{O}_{4} / \mathrm{CuSilicate}$ in the solution containing $20 \mathrm{mM}$ phosphate at $\mathrm{pH} 8.0$ (a). and Linear fitting of adsorption isotherms plots Langmuir model (b)

Table 3. Properties of different adsorbents for $\mathrm{BHb}$ capture

\begin{tabular}{cc}
\hline Adsorbent & Capacity $\left(\mathrm{mg} \mathrm{g}^{-1}\right)$ \\
\hline $\mathrm{Cu}$-IDA-silica-coated $\mathrm{Fe}_{3} \mathrm{O}_{4}$ & $418.6[15]$ \\
$\mathrm{Fe}_{3} \mathrm{O}_{4} @ \mathrm{PVBC} @ \mathrm{IDA}-\mathrm{Ni}$ & $1988[13]$ \\
$\mathrm{Magnetic} \mathrm{HCNTs}$ & $2200[24]$ \\
$\mathrm{Fe}_{3} \mathrm{O}_{4} @ \mathrm{SiO}_{2} @ \mathrm{IL}$ & $2150[38]$ \\
$\mathrm{CuFe}_{2} \mathrm{O}_{4} \mathrm{MNCs}$ & $4175[39]$ \\
$\mathrm{CNTs} / \mathrm{Fe}_{3} \mathrm{O}_{4} @ \mathrm{CuSilicate}$ & $302.3[40]$ \\
$\mathrm{Fe}_{3} \mathrm{O}_{4} / \mathrm{Cusilicate}$ & \\
\hline
\end{tabular}

Moreover, the single protein $\mathrm{BHb}\left(0.2 \mathrm{mg} \mathrm{mL}^{-1}\right)$ and BSA $\left(0.2 \mathrm{mg} \mathrm{mL} L^{-1}\right)$, a binary protein mixture containing $0.2 \mathrm{mg} \mathrm{mL}^{-1} \mathrm{BHb}$ and BSA respectively were incubated with $\mathrm{Fe}_{3} \mathrm{O}_{4} / \mathrm{CuSilicate}$ for 2 hours at room temperature. The adsorbed proteins could be eluted by dimethyl imidazole solution $\left(0.2 \mathrm{~g} \mathrm{~mL}^{-1}\right)$. The protein concentration in the supernatant was analyzed using a UV-vis spectrophotometer at 280 and $406 \mathrm{~nm}$ for BSA and BHb respectively. As shown in Figure 9, the absorption intensity of BHb at $406 \mathrm{~nm}$ revealed the efficient removal of $\mathrm{BHb}$ from the single $\mathrm{BHb}$ solution, and the binary $\mathrm{BHb}$ and $\mathrm{BSA}$ solution (Figure 9A(b), C(b)), while the adsorption intensity of BSA exhibits a negligible decrease at $280 \mathrm{~nm}$ (Figure 9B). When BSA is used as a competitive protein, the amount of adsorbed BHb 
is lower than that of single $\mathrm{BHb}$ solution, which indicates that the interaction between proteins was not beneficial for the adsorption of the BHb. This is also in accordance with our previous works. [40] The difference on the adsorption capacity of $\mathrm{Fe}_{3} \mathrm{O}_{4} / \mathrm{CuSilicate}$ towards $\mathrm{BHb}$ and BSA may be attributed to the different histidine residues in the proteins. The captured $\mathrm{BHb}$ on the $\mathrm{Fe}_{3} \mathrm{O}_{4} / \mathrm{CuSilicate}$ composites could be released by the treatment of the composites with dimethyl imidazole solution $\left(0.2 \mathrm{~g} \mathrm{~mL}^{-1}\right)$. After complete desorption of His-tagged proteins, the $\mathrm{Fe}_{3} \mathrm{O}_{4} @ \mathrm{CuSilicate}$ composites could be reused after sonication in buffer to release the excess adsorbed dimethyl imidazole. Figure 9D is the recyclability of the $\mathrm{Fe}_{3} \mathrm{O}_{4} / \mathrm{CuSilicate}$ as the absorbent for $\mathrm{BHb}$. The relative $\mathrm{BHb}$ adsorption capacity for the reused $\mathrm{Fe}_{3} \mathrm{O}_{4} / \mathrm{CuSilicate}$ composites remained almost unchanged after five cycles of reuse, indicating the excellent recyclability.
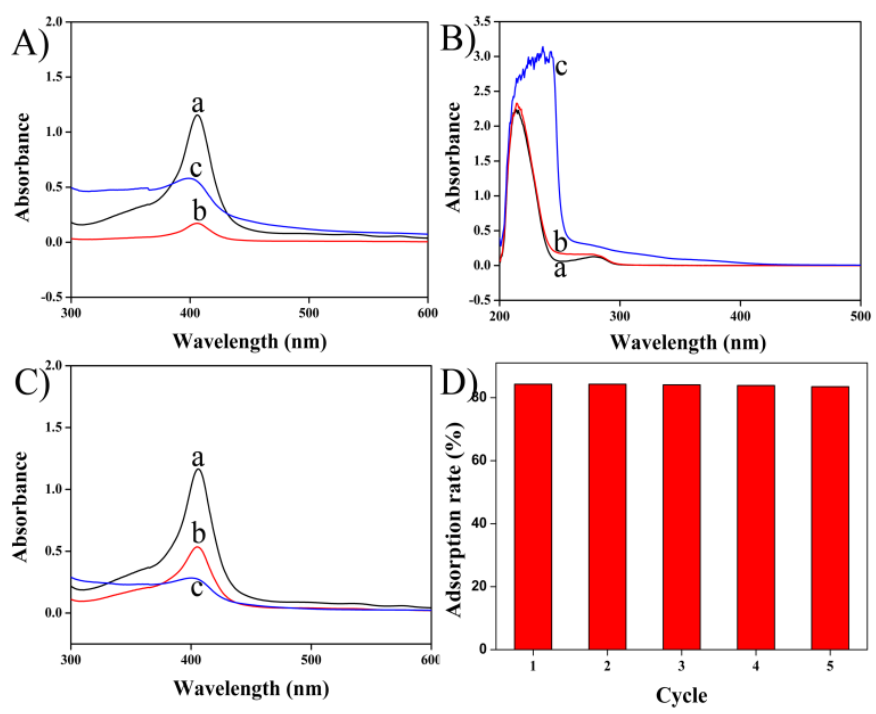

Figure 9. Curve a is the UV-vis spectrum of $0.2 \mathrm{mg} \mathrm{mL}^{-1}$ of the $\mathrm{BHb}(\mathrm{A}), \mathrm{BSA}(\mathrm{B}) \mathrm{BHb}$ and BSA mixture (C) before adsorption by $\mathrm{Fe}_{3} \mathrm{O}_{4} / \mathrm{CuSilicate}$. Curve $\mathrm{b}$ is the $\mathrm{UV}$-vis spectrum of supernatant of $\mathrm{BHb}(\mathrm{A}), \mathrm{BSA}(\mathrm{B}), \mathrm{BHb}$ and $\mathrm{BSA}$ mixture (C) after adsorbed by $\mathrm{Fe}_{3} \mathrm{O}_{4} / \mathrm{CuSilicate}$. Curve $\mathrm{c}$ is the UV-vis spectrum of desorption solution of the adsorbed 
protein by $\mathrm{Fe}_{3} \mathrm{O}_{4} / \mathrm{CuSilicate}$ in $\mathrm{BHb}(\mathrm{A}), \mathrm{BSA}(\mathrm{B}), \mathrm{BHb}$ and $\mathrm{BSA}$ mixture (C) using concentration of $0.2 \mathrm{~g} \mathrm{~mL}^{-1}$ of dimethyl imidazole solution as the eluent. $\mathrm{D}$ is the recyclability of the $\mathrm{Fe}_{3} \mathrm{O}_{4} / \mathrm{CuSilicate}$ as the absorbent for $\mathrm{BHb}$.

To further illustrate the practicability and selectivity of $\mathrm{Fe}_{3} \mathrm{O}_{4} / \mathrm{CuSilicate}$ to $\mathrm{HHb}$ and explore its application in the real samples (human blood), diluted 10-fold human blood was incubated with by $\mathrm{Fe}_{3} \mathrm{O}_{4} / \mathrm{CuSilicate}$. From the SDS-PAGE analysis (Figure 10), it could be seen that the $\mathrm{HHb}$ band obviously faded while the HSA band and other protein bands in human blood nearly remained as original (lane 3) after treatment with the $\mathrm{Fe}_{3} \mathrm{O}_{4} / \mathrm{CuSilicate}$. Notably, the eluted solution from $\mathrm{Fe}_{3} \mathrm{O}_{4} / \mathrm{CuSilicate}$ showed the $\mathrm{HHb}$, $\mathrm{HSA}$ band, which fully indicate that the $\mathrm{Fe}_{3} \mathrm{O}_{4} / \mathrm{CuSilicate}$ exhibit the specific absorption on his-tagged proteins (lane 4). Furthermore, the large gap between the HSA and $\mathrm{HHb}$ band of eluted solution further demonstrated that most of the protein adsorbed by $\mathrm{Fe}_{3} \mathrm{O}_{4} / \mathrm{CuSilicate}$ was $\mathrm{HHb}$. These results suggest that the remarkable merits of $\mathrm{Fe}_{3} \mathrm{O}_{4} / \mathrm{CuSilicate}$ for removing the abundant proteins $(\mathrm{HHb})$ in the real biological samples. 


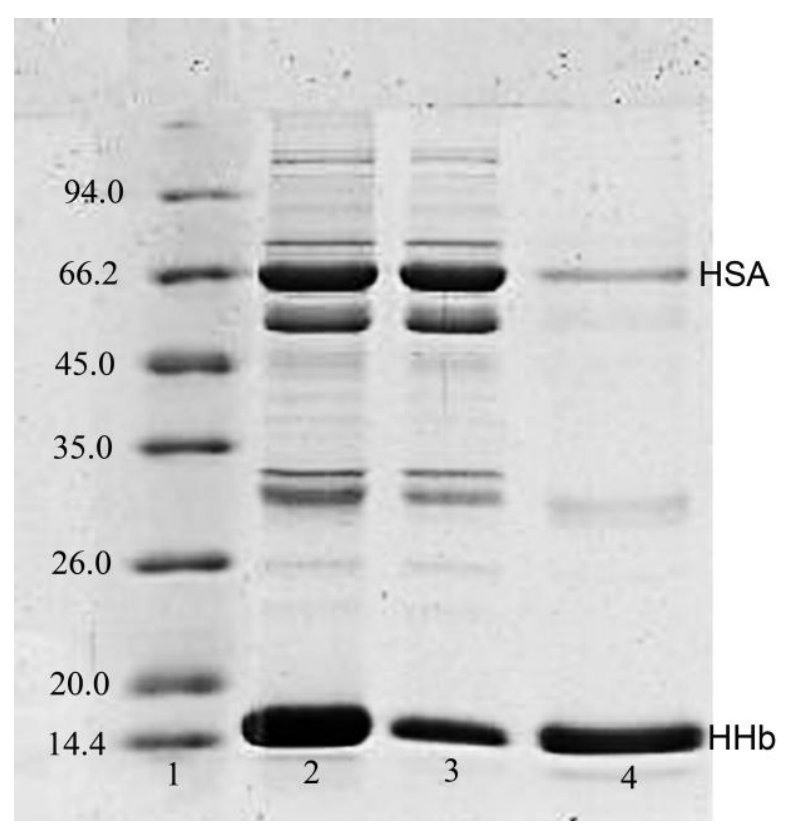

Figure 10. SDS-PAGE analysis of adsorption by $\mathrm{Fe}_{3} \mathrm{O}_{4} / \mathrm{CuSilicate}$ from solution. Lane 1, marker; lane 2, 10-fold human whole blood; lane 3, remaining human whole blood solution after adsorption by $\mathrm{Fe}_{3} \mathrm{O}_{4} / \mathrm{CuSilicate}$; lane 4, the eluted 10 -fold human whole blood by $0.2 \mathrm{~g}$ $\mathrm{mL}^{-1}$ dimethyl imidazole solution

\section{Conclusions}

The sea urchin-like $\mathrm{Fe}_{3} \mathrm{O}_{4} @$ CuSilicate composites composed of copper silicate nanotubes and magnetic nanoparticles cores have been successfully fabricated via a high temperature decompositions method combined with a facile hydrothermal approach. The synthesized magnetic hierarchical copper silicate hollow spheres exhibited large specific surface area and an excellent adsorption capacity on BHb. Moreover, the BET surface area of the $\mathrm{Fe}_{3} \mathrm{O}_{4} / \mathrm{CuSilicate}$ can be easily adjusted by using different amount of magnetic nanoparticles decorated silica spheres or the $\mathrm{SiO}_{2} @ \mathrm{Fe}_{3} \mathrm{O}_{4}$ composites with different diameter of $\mathrm{SiO}_{2}$. In addition, the $\mathrm{Fe}_{3} \mathrm{O}_{4} @ \mathrm{CuSilicate}$ composites were successfully employed to selectively bind and remove abundant proteins $(\mathrm{HHb})$ from human blood samples. The good results 
demonstrated their potential in separation of His-rich proteins from biological samples. Significantly, the as-prepared magnetic hierarchical copper silicate hollow spheres could be easily separated by commercial magnet. Furthermore, this strategy can be extended as a general method to prepare other magnetic metal silicate hollow spheres.

\section{Acknowledgements}

The authors are grateful to the financial support by the National Science Foundation of China (No 21305086). The Natural Science Foundation of Shanghai City (13ZR141830), Research Innovation Program of Shanghai Municipal Education Commission (14YZ138), the Special Scientific Foundation for Outstanding Young Teachers in Shanghai Higher Education Institutions (ZZGJD13016, ZZGJD13018)

\section{References}

[1] R. Ahrends, S. Pieper, A. Kühn, H. Weisshoff, M. Hamester, T. Lindemann, C. Scheler, K. Lehmann, K. Taubner, M.W. Linscheid, A Metal-coded Affinity Tag Approach to Quantitative Proteomics, Molecular \& Cellular Proteomics, 6 (2007) 1907-1916.

[2] J. Arnau, C. Lauritzen, G.E. Petersen, J. Pedersen, Current strategies for the use of affinity tags and tag removal for the purification of recombinant proteins, Protein Expr Purif, 48 (2006) 1-13.

[3] M. Shao, F. Ning, J. Zhao, M. Wei, D.G. Evans, X. Duan, Preparation of $\mathrm{Fe}_{3} \mathrm{O}_{4} @ \mathrm{SiO}_{2} @$ layered double hydroxide core-shell microspheres for magnetic separation of proteins, J Am Chem Soc, 134 (2012) 1071-1077.

[4] G. Zhen, D. Falconnet, E. Kuennemann, J. Vörös, N.D. Spencer, M. Textor, S. Zürcher, 
Nitrilotriacetic Acid Functionalized Graft Copolymers: A Polymeric Interface for Selective and Reversible Binding of Histidine-Tagged Proteins, Adv Funct Mater, 16 (2006) 243-251.

[5] R. Ahrends, S. Pieper, B. Neumann, C. Scheler, M.W. Linscheid, Metal-Coded Affinity Tag Labeling: A Demonstration of Analytical Robustness and Suitability for Biological Applications, Anal Chem, 81 (2009) 2176-2184.

[6] N.O. Fischer, C.D. Blanchette, B.A. Chromy, E.A. Kuhn, B.W. Segelke, M. Corzett, G. Bench, P.W. Mason, P.D. Hoeprich, Immobilization of His-Tagged Proteins on Nickel-Chelating Nanolipoprotein Particles, Bioconjugate Chem, 20 (2009) 460-465.

[7] J. Kim, H.Y. Park, J. Kim, J. Ryu, Y. Kwon do, R. Grailhe, R. Song, Ni-nitrilotriacetic acid-modified quantum dots as a site-specific labeling agent of histidine-tagged proteins in live cells, Chem Commun (Camb), (2008) 1910-1912.

[8] J. Bao, W. Chen, T. Liu, Y. Zhu, P. Jin, L. Wang, J. Liu, Y. Wei, Y. Li, Bifunctional Au-Fe $\mathrm{O}_{4}$ Nanoparticles for Protein Separation, ACS Nano, 1 (2007) 293-298.

[9] Y.-C. Lin, M.-R. Liang, Y.-C. Lin, C.-T. Chen, Specifically and Reversibly Immobilizing Proteins/Enzymes to Nitriolotriacetic-Acid-Modified Mesoporous Silicas through Histidine Tags for Purification or Catalysis, Chem-Eur J, 17 (2011) 13059-13067.

[10] X. Zou, K. Li, Y. Zhao, Y. Zhang, B. Li, C. Song, Ferroferric oxide/L-cysteine magnetic nanospheres for capturing histidine-tagged proteins, Journal of Materials Chemistry B, 1 (2013) 5108-5113.

[11] S.H. Kim, M. Jeyakumar, J.A. Katzenellenbogen, Dual-Mode Fluorophore-Doped Nickel Nitrilotriacetic Acid-Modified Silica Nanoparticles Combine Histidine-Tagged Protein Purification with Site-Specific Fluorophore Labeling, J. Am. Chem. Soc., 129 (2007) 
$13254-13264$.

[12] H.-Y. Xie, R. Zhen, B. Wang, Y.-J. Feng, P. Chen, J. Hao, $\mathrm{Fe}_{3} \mathrm{O}_{4} / \mathrm{Au}$ Core/Shell Nanoparticles Modified with $\mathrm{Ni}^{2+}$-Nitrilotriacetic Acid Specific to Histidine-Tagged Proteins, The Journal of Physical Chemistry C, 114 (2010) 4825-4830.

[13] J.L. Cao, X.H. Zhang, X.W. He, L.X. Chen, Y.K. Zhang, Facile synthesis of a $\mathrm{Ni}(\mathrm{II})$-immobilized core-shell magnetic nanocomposite as an efficient affinity adsorbent for the depletion of abundant proteins from bovine blood, Journal of Materials Chemistry B, 1 (2013) $3625-3632$.

[14] G.Q. Jian, Y.X. Liu, X.W. He, L.X. Chen, Y.K. Zhang, Click chemistry: a new facile and efficient strategy for the preparation of $\mathrm{Fe}_{3} \mathrm{O}_{4}$ nanoparticles covalently functionalized with IDA-Cu and their application in the depletion of abundant protein in blood samples, Nanoscale, 4 (2012) 6336-6342.

[15] M. Zhang, D. Cheng, X. He, L. Chen, Y. Zhang, Magnetic Silica-Coated Sub-Microspheres with Immobilized Metal Ions for the Selective Removal of Bovine Hemoglobin from Bovine Blood, Chemistry-an Asian Journal, 5 (2010) 1332-1340.

[16] M. Zhang, X. He, L. Chen, Y. Zhang, Preparation of IDA-Cu functionalized core-satellite $\mathrm{Fe}_{3} \mathrm{O}_{4} /$ polydopamine/Au magnetic nanocomposites and their application for depletion of abundant protein in bovine blood, J. Mater. Chem., 20 (2010) 10696-10704.

[17] M. Zhang, X.W. He, L.X. Chen, Y.K. Zhang, Preparation and characterization of iminodiacetic acid-functionalized magnetic nanoparticles and its selective removal of bovine hemoglobin, Nanotechnology, 22 (2011) 065705.

[18] Q. Fang, S. Xuan, W. Jiang, X. Gong, Yolk-like Micro/Nanoparticles with Superparamagnetic 
Iron Oxide Cores and Hierarchical Nickel Silicate Shells, Adv Funct Mater, 21 (2011) 1902-1909.

[19] Z. Liu, M. Li, X. Yang, M. Yin, J. Ren, X. Qu, The use of multifunctional magnetic mesoporous core/shell heteronanostructures in a biomolecule separation system, Biomaterials, 32 (2011) 4683-4690.

[20] B. Wang, W. Meng, M. Bi, Y. Ni, Q. Cai, J. Wang, Uniform magnesium silicate hollow spheres as high drug-loading nanocarriers for cancer therapy with low systemic toxicity, Dalton Trans, 42 (2013) 8918-8925.

[21] Y. Wu, G. Chang, Y. Zhao, Y. Zhang, Preparation of hollow nickel silicate nanospheres for separation of His-tagged proteins, Dalton Trans, 43 (2014) 779-783.

[22] R. Jin, Y. Yang, Y. Li, L. Fang, Y. Xing, S. Song, In situ assembly of well-dispersed gold nanoparticles on hierarchical double-walled nickel silicate hollow nanofibers as an efficient and reusable hydrogenation catalyst, Chem Commun (Camb), 50 (2014) 5447-5450.

[23] R. Jin, Y. Yang, Y. Xing, L. Chen, S. Song, R. Jin, Facile Synthesis and Properties of Hierarchical Double-Walled Copper Silicate Hollow Nanofibers Assembled by Nanotubes, ACS Nano, 8 (2014) 3664-3670.

[24] M. Zhang, B. Wang, Y. Zhang, W. Li, W. Gan, J. Xu, Facile synthesis of magnetic hierarchical copper silicate hollow nanotubes for efficient adsorption and removal of hemoglobin, Dalton Trans, 45 (2016) 922-927.

[25] W. Stöber, A. Fink, E. Bohn, Controlled growth of monodisperse silica spheres in the micron size range, J Colloid Interface Sci, 26 (1968) 62-69.

[26] H. Qu, S. Tong, K. Song, H. Ma, G. Bao, S. Pincus, W. Zhou, C. O'Connor, Controllable in situ synthesis of magnetite coated silica-core water-dispersible hybrid nanomaterials, Langmuir, 
29 (2013) 10573-10578.

[27] Y. Wang, G. Wang, H. Wang, C. Liang, W. Cai, L. Zhang, Chemical-template synthesis of micro/nanoscale magnesium silicate hollow spheres for waste-water treatment, Chemistry, 16 (2010) 3497-3503.

[28] C.Y. Cao, F. Wei, J. Qu, W.G. Song, Programmed synthesis of magnetic magnesium silicate nanotubes with high adsorption capacities for lead and cadmium ions, Chemistry, 19 (2013) $1558-1562$.

[29] C.X. Gui, Q.Q. Wang, S.M. Hao, J. Qu, P.P. Huang, C.Y. Cao, W.G. Song, Z.Z. Yu, Sandwichlike magnesium silicate/reduced graphene oxide nanocomposite for enhanced $\mathrm{Pb}^{2+}$ and methylene blue adsorption, Acs Appl Mater Interfaces, 6 (2014) 14653-14659.

[30] C. Tang, J. Sheng, C. Xu, S.M.B. Khajehbashi, X. Wang, P. Hu, X. Wei, Q. Wei, L. Zhou, L. Mai, Facile synthesis of reduced graphene oxide wrapped nickel silicate hierarchical hollow spheres for long-life lithium-ion batteries, Journal of Materials Chemistry A, 3 (2015) 19427-19432.

[31] J. Liu, J. Cheng, R. Che, J. Xu, M. Liu, Z. Liu, Synthesis and Microwave Absorption Properties of Yolk-Shell Microspheres with Magnetic Iron Oxide Cores and Hierarchical Copper Silicate Shells, ACS Appl Mater Interfaces, 5 (2013) 2503-2509.

[32] M. Zhang, X. Zhang, X. He, L. Chen, Y. Zhang, A self-assembled polydopamine film on the surface of magnetic nanoparticles for specific capture of protein, Nanoscale, 4 (2012) 3141-3147. [33] Y. Wang, G. Wang, H. Wang, W. Cai, L. Zhang, One-pot synthesis of nanotube-based hierarchical copper silicate hollow spheres, Chem Commun (Camb), (2008) 6555-6557.

[34] E. Nossol, A.B.S. Nossol, S.-X. Guo, J. Zhang, X.-Y. Fang, A.J.G. Zarbin, A.M. Bond, 
Synthesis, characterization and morphology of reduced graphene oxide-metal-TCNQ nanocomposites, Journal of Materials Chemistry C, 2 (2014) 870-878.

[35] R. Guillet-Nicolas, J.-L. Bridot, Y. Seo, M.-A. Fortin, F. Kleitz, Enhanced Relaxometric Properties of MRI "Positive" Contrast Agents Confined in Three-Dimensional Cubic Mesoporous Silica Nanoparticles, Adv Funct Mater, 21 (2011) 4653-4662.

[36] L. Tan, D. Chen, H. Liu, F. Tang, A Silica Nanorattle with a Mesoporous Shell: An Ideal Nanoreactor for the Preparation of Tunable Gold Cores, Adv Mater, 22 (2010) 4885-4889.

[37] N. Zhang, X. Fu, Y.-J. Xu, A facile and green approach to synthesize $\mathrm{Pt} @ \mathrm{CeO}_{2}$ nanocomposite with tunable core-shell and yolk-shell structure and its application as a visible light photocatalyst, J. Mater. Chem., 21 (2011) 8152-8158.

[38] Y. Wei, Y. Li, A. Tian, Y. Fan, X. Wang, Ionic liquid modified magnetic microspheres for isolation of heme protein with high binding capacity, Journal of Materials Chemistry B, 1 (2013) 2066-2071.

[39] J. Zheng, Z. Lin, W. Liu, L. Wang, S. Zhao, H. Yang, L. Zhang, One-pot synthesis of $\mathrm{CuFe}_{2} \mathrm{O} 4$ magnetic nanocrystal clusters for highly specific separation of histidine-rich proteins, Journal of Materials Chemistry B, 2 (2014) 6207-6214.

[40] M. Zhang, Y. Wang, Y. Zhang, L. Ding, J. Zheng, J. Xu, Preparation of Magnetic Carbon Nanotubes with Hierarchical Copper Silicate Nanostructure for Efficient Adsorption and Removal of Hemoglobin, Applied Surface Science 375 (2016) 154-161. 


\section{Graphical abstract}

Sea Urchin-like Magnetic Copper Silicate Hollow Spheres were synthesized via an in situ chemical conversion route, which can be a good adsorbent for removing the high abundant proteins in human blood.

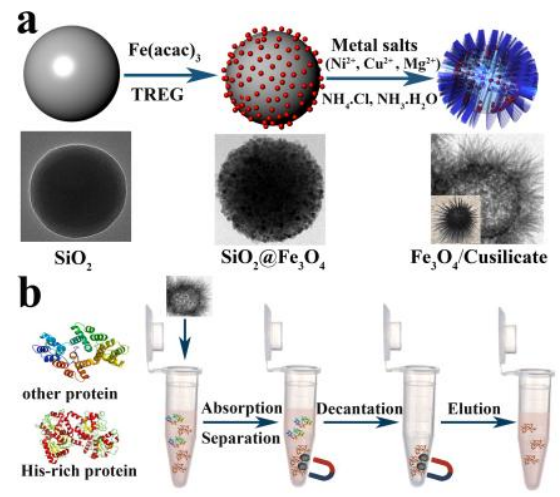

